\title{
Germination of Seeds of Interspecific Hybrid Caiaué $\times$ Oil Palm Submitted to the Mechanical Depulping
}

\author{
Thaís Moura Maquiné1, Alex Queiroz Cysne2, Wanderlei Antônio Alves de Lima², \\ Samuel Campos Abreu ${ }^{3}$, Márcia Green ${ }^{4}$, Sara de Almeida Rios ${ }^{2 *}$ \\ ${ }^{1}$ University Center North, Manaus, Brazil \\ ${ }^{2}$ Embrapa Western Amazon, Manaus, Brazil \\ ${ }^{3}$ Embrapa Products and Market, Brasília, Brazil \\ ${ }^{4}$ Federal University of Amazonas, Manaus, Brazil \\ Email: sara.rios@embrapa.br
}

Received 12 July 2014; revised 16 August 2014; accepted 3 September 2014

Copyright @ 2014 by authors and Scientific Research Publishing Inc.

This work is licensed under the Creative Commons Attribution International License (CC BY).

http://creativecommons.org/licenses/by/4.0/

c) (i) Open Access

\begin{abstract}
Oil palm seeds respond well to protocols of dormancy break, however, the seeds of interspecific hybrid (HIE) (caiaué $\times$ oil palm) have lower germination rates. The mechanical depulping can affect the potential of germination of seeds, therefore the objective of this study was to evaluate the mechanical depulping on the seed germination, vigor and viability of embryos HIE BRS Manicoré. $A$ randomized block design with five treatments, based on the depulping time and on the percentage of mesocarp on the seed with four replications was used. The percentage of seed germination, the germination speed index (GSI), the percentage of fungi and abnormal seeds and vigor and viability of embryos were evaluated. There was no statistical difference $(p<0.05)$ between treatments for all variables. The average of germination at 35 days was $45.34 \%$ and embryos showed high to medium vigor by the tetrazolium test. The mechanical depulping do not affect the seed germination, nor the viability and vigor of embryos HIE BRS Manicoré. It is recommended that the fruits of HIE BRS Manicoré remain in depulper machine for $\mathbf{4 0}$ minutes to completely remove the mesocarp residue.
\end{abstract}

\section{Keywords}

Elaeis oleifera, E. guineensis, Percentage of Germination, Mechanical Damage, Tetrazolium Test

\footnotetext{
${ }^{*}$ Corresponding author.
} 


\section{Introduction}

Embrapa holds the registration of seven oil palm cultivars and one interspecific hybrid (HIE) BRS Manicoré (E. oleifera $\times$ E. guineensis) recommended for areas of incidence of a disorder called Amarelecimento Fatal-AF [1]. The commercial seed production of these cultivars with high genetic performance is one of the most important contributions for the development of the national palm culture [2].

Considering the quality of the seeds and the necessity for increased efficiency in processing, especially for the gradual increase in demand for these, Embrapa works with new strategies to expand its participation as a supplier of seeds, as the increase on the germination potential of seeds in order to considerably increase its offer to the Brazilian market.

The oil palm seeds have low germination rates due to the dormancy presented after physiological maturity. The germination of these seeds can take years, having very low rates [3] —a process that can be accelerated by the use of specific protocols to break dormancy [4]. In general, oil palm seed responds well to these protocols, with an average of 85\% of germination [4]. However, for commercial seeds of HIE BRS Manicoré, germinal indices are significantly lower, with an average of $60 \%$ of germination, for commercial seed produced by Embrapa. Guerrero et al. [5] found an average of $24.5 \%$ of germination for seeds of interspecific hybrids (E. oleifera $\times$ E. guineensis Cereté type) in a total of 45 different treatments evaluating moisture, temperature and days of heating the seeds, and the best treatment had an average of $40.4 \%$.

Several external factors such as temperature, humidity, processing, and others affect seed germination, and can cause numerous losses as the fall of germination, vigor loss, the lower commercial value, the ease of entry of insects and microorganisms, lower potential storage and loss in physical purity [6]-[9].

The mechanical damage is seen by many technologists as one of the most serious impacts on yield of seeds together with the varietal mixtures. The injuries affect germination, seedling development, susceptibility to diseases, plant growth and development and grain yield. The germination rate and seedling quality are influenced by the location of damage, the embryos and especially the central part being the more sensitive [10].

In the commercial production of oil palm seeds, the use of a mechanized depulper [11] for the extraction of mesocarp covering the seed (endocarp, endosperm and embryo) is common. This machine consists of a metal cylinder (Figure 1), with an inner rotating disc where the fruit is deposited. The pulping process occurs by the friction of the fruit with the wall of the rotating disc in combination with a continuous flow of water separating the flesh from the seed.

There is no documentation on mechanical damage to the seed of oil palm during processing, but some parallels may be drawn from experience from agricultural seeds. In general, smaller and spherical seeds tend to suffer less mechanical damage compared to those elongated and irregular in shape [12]. In fruits of Annona crassiflora processed through a concrete mixer, the speed of rotation and the time used in the separation of the seeds from the pulp do not cause mechanical damage to the seeds [13]. In coffee seeds, the parchment removal in palette scarifier resulted in the total loss of seed germination [14] as well as the occurrence of mechanically damaged with impaired and lower germination values by the use of peeling machine [15].

It is possible that the excessive permanence of seeds of interspecific hybrid BRS Manicoré in the mechanical depulper can cause damage to the embryous, affecting the viability and vigor, and hence the germination rates. Schmidt [10] reported that minor damage during processing may not immediately affect viability but can cause reduction of the vigour of the seedlings. Considering the hypothesis that the mechanical depulping process can affect seed germination, the objective of this study was to evaluate the mechanical depulping of fruits on seed germination and viability and vigor of embryos from HIE BRS Manicoré.

\section{Material and Methods}

The experiment was conducted at the Experimental Station of Rio Urubu, Embrapa Western Amazon, located in the city of Rio Preto da Eva/AM, Km 54, latitude $2^{\circ} 30^{\prime} \mathrm{S}$, longitude $59^{\circ} 25^{\prime} \mathrm{W}$ and elevation of $200 \mathrm{~m}$. Bunches of American oil palm were collected from genotypes used in commercial seed production of HIE BRS Manicoré.

Bunches were harvested at the physiological maturity, around five to six months after pollination [4]. The spikelets were removed manually with the aid of a hatchet to remove the rachis, and subsequently placed in plastic boxes where remained for three days for fermentation. The fruits were separated from the spikelets and randomly assigned to form the experimental unit consisted of $10 \mathrm{~kg}$ of fruit. Treatments were applied on the fruits, inside the electrical mechanized depulper. This machine is metal cylinder $62.5 \mathrm{~cm}$ in diameter and $71 \mathrm{~cm}$ 
height (Figure 1(a)) consisted of a centrifugal (horizontal rotating plate) with metal fins (Figure 1(b)) and an engine of $5 \mathrm{hp} \mathrm{(Figure} \mathrm{1).} \mathrm{Water} \mathrm{was} \mathrm{supplied} \mathrm{for} \mathrm{flushing} \mathrm{the} \mathrm{pulp} \mathrm{from} \mathrm{the} \mathrm{fruit} \mathrm{by} \mathrm{a} \mathrm{perforated} \mathrm{pipe} \mathrm{at} \mathrm{the} \mathrm{top}$ of the drum. The water and waste were drained through radial slots cut in the rotating plate and off the edge of the plate (Figure 1(a)). The depulping was carried out by friction of the fruit against the walls of the depulper, with the continuous supply of water for cleaning the seeds.

The experimental design used was a randomized block with five treatments and four replications, using five times of permanence of the seeds inside the depulper (10 minutes until 50 minutes) and then classifying the seeds of each treatment according to the approximate percentage of mesocarp covering the seed (defined by image only), thus described: 1) 10 minutes in the depulper with at least $50 \%$ of fruit covered by the mesocarp; 2) 20 minutes in the depulper, with at least $25 \%$ fruit covered by the mesocarp; 3 ) 30 minutes in the depulper with at least $10 \%$ fruit covered by the mesocarp; 4 ) 40 minutes in the depulper without fruits covered by mesocarp; 5) 50 minutes in the depulper, without fruit covered by mesocarp.

After the depulping process, for those seeds that did not have complete removal of the mesocarp in mechanized process, manual scraping was performed with the aid of a knife, exactly as in commercial seed production, to prevent the proliferation of fungi, without affecting seed germination because it was performing extremely superficial. Then the seeds were placed in a suspended mesh in the shade, to remove excess surface moisture, with subsequent storage in a cold chamber at $21^{\circ} \mathrm{C}$ until the evaluations start.

The seeds were treated with fungicide of contact and systemic $0.2 \%$ of Carboxin ${ }^{\circledR}$ product (carboxanilide) + Thiram ${ }^{\circledR}$ (dimethyldithiocarbamate) 200 SC with immersion for five minutes, and were performed with a further adjustment of moisture for $20 \%-21 \%$. Then the seeds were placed in plastic bags and taken into the germination room, where it remained for 75 days at $39^{\circ} \mathrm{C} \pm 1^{\circ} \mathrm{C}$ to break dormancy [4]. Every 15 days a round was performed to visually eliminate seeds attacked by fungi and to exchange the air of the bags.

After the departure of germination room, seeds were rehydrated in water tanks with oxygen for eight days and then dried in the shade until reach humidity around $23 \%$ to $25 \%$. The next step was the routing to the germination room with temperature of $25^{\circ} \mathrm{C}$ until $27^{\circ} \mathrm{C}$.

Germination started to be evaluated seven days after entry in the germination room. The germinal indexes (weekly evaluated-screening) were performed, totaling 35 days being the 1st screening at 7 days, the 2nd screening at 14 days, the 3rd screening at 21 days, the 4th screening at 28 days and 5th screening at 35 days; the index of germination speed (IGS) — calculated as Maguire [16], with adaptations (IGS = G1/N1 + G2/N2 + Gn/Nn where: G1, G2, Gn = number of seedlings germinated in the first, second, and $G^{\text {th }}$ screening and N1, N2, Nn = number of days from the first, second, until the $\mathrm{n}^{\text {th }}$ sorting); the incidence of fungi and the percentage of abnormal
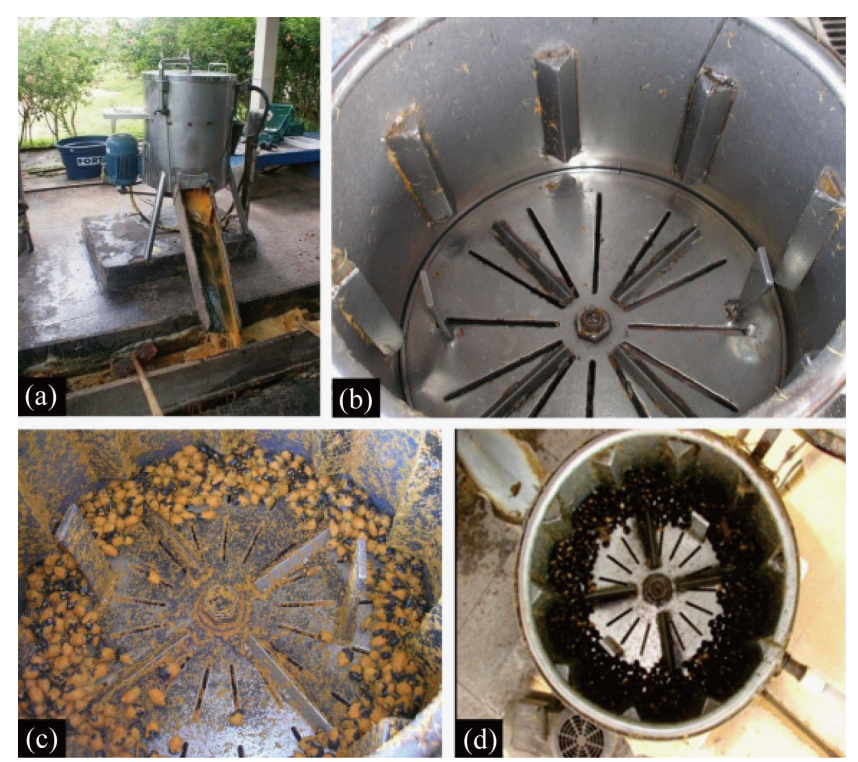

Figure 1. Mechanical depulper on the commercial production of oil palm seeds. (a) Front view; (b) Top view of the turntable; (c) Fruits in the depulper process; (d) Newly depulped fruit. 
seeds.

For the evaluation of vigor and viability of embryos through the tetrazolium test, breaking of the endocarp was performed with the removal of endosperm and embryo, and with the aid of a knife, was made the extraction of the embryos. After it, the embryous were placed in moistened germitest paper for hydration, with preconditioning in BOD of $30^{\circ} \mathrm{C}$ to $35^{\circ} \mathrm{C}$ for 16 hours, according to the methodology described by Green [17], adapted from Murugesan et al. [18]. The experimental plot consisted of 25 embryos. These were immersed in a solution of 2,3,5-triphenyl tetrazolium chloride in a concentration of $0.075 \%$ covered with aluminum foil and placed in a growth chamber in the dark at $40^{\circ} \mathrm{C}$ for 4 hours until the wash in running water with subsequent evaluation of the vigor. It was performed the evaluation of the first three classes (high to medium vigor) through the classes defined by Green [17]: Class 1-the most high vigor: homogeneous coloring (red or pink), tigelo featuring red or pink coloring, haustorium with pink or red coloration; Class 2-high vigor: tigelo with homogenous color and haustorium less than 25\% colorless; and Class 3-medium vigor: tigelo with homogenous color and haustorium between $25 \%$ to $50 \%$ without color below the median region.

The data were transformed into arcsine of the square root of $\times / 100$, to attend the normal distribution, being $\times$ the observed values. The analysis of variance and means was performed by Tukey test at $5 \%$ probability using the Genes software [19].

\section{Results and Discussion}

Analysis of variance showed no significance $(\mathrm{p}<0.05)$ between treatments for any variable evaluated (percentage of germination, fungi and abnormal seeds, IGS and viability and vigor of embryos) (data not shown).

Figure 2 shows a trend of decreasing on the percentage of seed germination with increasing of the time of permanence in mechanized depulper, during processing of seeds. However, analysis of variance showed no significance $(\mathrm{p}<0.05)$ between treatments for this variable. The percentage of germination for the five treatments evaluated at 35 days showed variation of $38.99 \%$ to $52.98 \%$ (Figure 2). This average (45.34\%) was lower than that recorded in the database of the Escritório de Negócios da Amazônia-ENA, local of commercial production of the BRS Manicoré seeds (58.71\% for seeds produced in 2011, 2012 and 2013), which was expected since were compared lots of different plants with production in different years. It is known that the germination of palm seeds varies by plant, year and region of evaluation [20].

There was also no statistical difference for the percentage of germination at 14 days (Table 1), a period considered as a possible reference for the evaluation of seed vigor, due to the largest number of germinated seeds [21] in relation to other screens (weekly periods of evaluation and counting of germinated seeds). In the genus Elaeis, the germination process is not regular, featuring seed germination as being continuous over weeks [22]

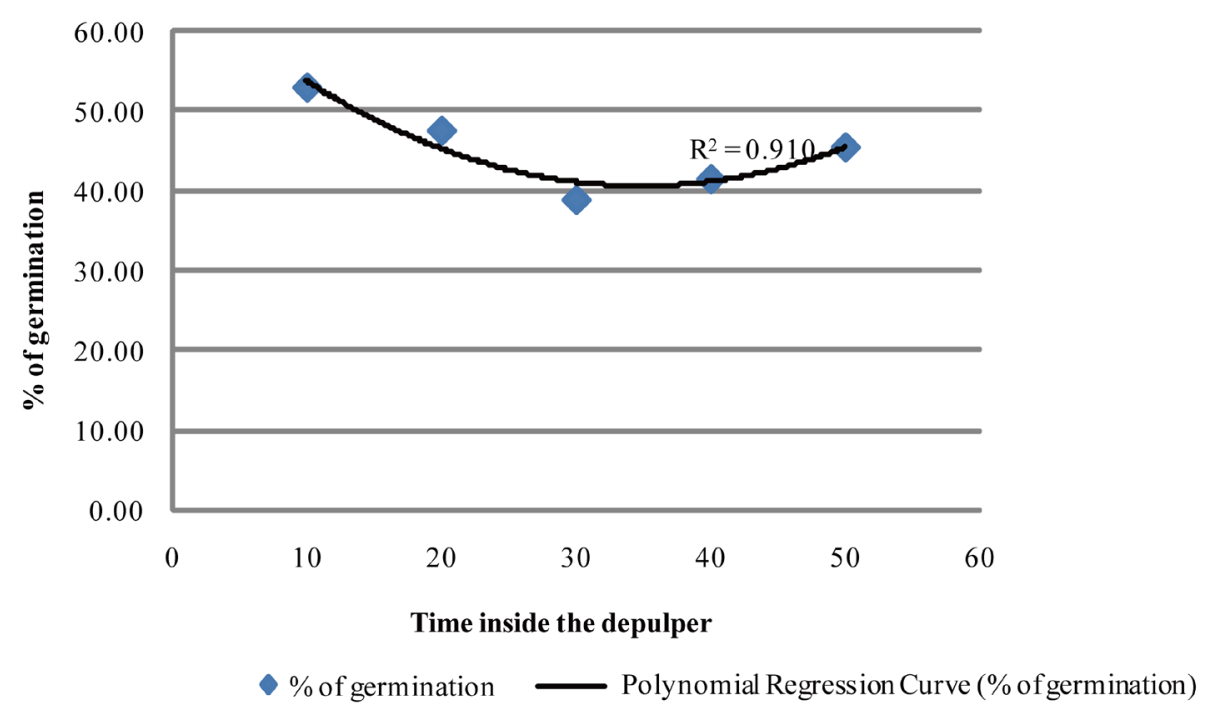

Figure 2. Percentage of germination of seeds of the interspecific hybrid BRS Manicoré submitted to five treatments (time) based on a scale of mechanical depulping of fruits. 
Table 1. Percentage of germination at 14 days (G14), fungi and abnormal seeds, index of germination speed (IGS) and percentage of viability and vigor of embryous by tetrazolium test for fruits of interespecific hybrid BRS Manicoré (caiaué $\times$ oil palm) submitted to five treatments during the mechanical depulping.

\begin{tabular}{|c|c|c|c|c|c|}
\hline \multirow{2}{*}{ Treatments* } & G14 & Fungi & Abnormal seeds & \multirow{2}{*}{ IGS } & \multirow{2}{*}{ Vigor (Tetrazolium) } \\
\hline & \multicolumn{3}{|c|}{ 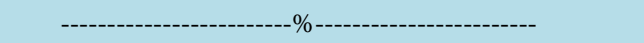 } & & \\
\hline 1 & 18.58 & 0.87 & 1.75 & 32.43 & 84 \\
\hline 2 & 21.04 & 1.18 & 3.72 & 25.19 & 64 \\
\hline 3 & 14.94 & 0.49 & 4.14 & 24.56 & 74 \\
\hline 4 & 14.91 & 2.13 & 4.51 & 19.04 & 72 \\
\hline 5 & 12.07 & 1.86 & 3.70 & 19.90 & 82 \\
\hline Média & 16.30 & 1.31 & 3.56 & 24.22 & 75.2 \\
\hline
\end{tabular}

1. 10 minutes in the depulper with at least $50 \%$ of fruit covered by the mesocarp; 2.20 minutes in the depulper, with at least $25 \%$ fruit covered by the mesocarp; 3.30 minutes in the depulper with at least $10 \%$ fruit covered by the mesocarp; 4.40 minutes in the depulper without fruits covered by mesocarp; 5.50 minutes in the depulper, without fruit covered by mesocarp.

[23]. There seems to be a higher rate of abnormal seedlings during the pre-nursery from seeds germinated from the later scrennings [22], but there is no detailed information to establish the threshold screening (weeks for germination) without such abnormalities.

The results showed that the mechanical depulping process of HIE BRS Manicoré seeds did not affect the percentage of germination nor the vigor of the embryos. Hussey [3] reports that the low rate of natural germination of oil palm is due to the endocarp which is hard and dense, including being responsible for the mechanical resistance to oxygen absorption. The oil palm fruit is a drupe divided into mesocarp, endocarp, endosperm and embryo [24]. According to endocarp thickness, the genotypes are divided into three varieties, Dura, Tenera and Pisifera groups, trait genetically controlled by the gene Sh (Shell thickness). The Dura type, characterized by genotypes $\mathrm{Sh}+\mathrm{Sh}+$ features fruits with hard endocarp and thin mesocarp [25], and are the genotypes used as commercial plants for fruit production, which are pollinated with genotypes from Pisifera type (Sh - Sh-), giving rise to the hybrid tenera (Sh + Sh-). We suggest that the hardness of endocarp probably was the determining factor in protecting the embryo against the possible mechanical damage by the use of a mechanized depulper.

One of the most interesting results of this experiment was to verify that on the treatment 4, the permanence of the seeds for 40 minutes in the mechanized depulper featured low percentage of mesocarp residue covering the seed. As mechanical depulping did not affect the percentages of germination of seeds of interspecific hybrid BRS Manicoré, is recommended that the fruit standing for 40 minutes inside this machine until there is a maximum withdrawal of mesocarp. In the commercial production of HIE BRS Manicoré there was the need for manual removal of the fruit mesocarp, an activity that involves the handling of knife, is time consuming (on average are 500 seeds per bunch), and require trained manpower. We must consider that, although the treatment 5 was not statistically different from the others, it is not recommended that fruit remain in mechanical depulper over 40 minutes long, since under these conditions there was the presence of broken seeds after depulping (data not shown).

The results for the percentage of fungi were relatively low, ranging from $0.87 \%$ to $2.13 \%$ (Table 1). Siqueira et al. [26] reported incidence of fungi for the interspecific hybrid seeds BRS Manicoré and oil palm of $18 \%$ on the depulping step, $29 \%$ on the termogerminator and $21 \%$ in the storage process, but without the use of fungicides. Whereas the standard procedure for the production of seeds of HIE, with immersion of the seeds on the fungicide solution, the results were inferior to those observed in the database of the ENA of 5\%. More than 20 species of fungi may be associated with seed oil palm, but most of them are contaminants [23]. The incidence of microorganisms is one of the causes of abnormalities and injury to seedlings and seed deterioration [27]. The most severe problems related to diseases of plants occur during formation and germination of seedlings in the nursery and in most cases are caused by fungi [23].

Figure 3 shows some abnormalities observed during the process of germination in oil palm. The percentage of abnormal seeds on this trial ranged from $1.75 \%$ to $4.51 \%$ (Table 1 ), with an average of $3.56 \%$. The result found was lower than the average of the ENA, that is $6 \%$ of abnormal for commercial seed production of the HIE BRS Manicoré. Mora et al. [23] reported that a greater number of failures during germination are also associated with the appearance of a higher percentage of abnormal seedlings in the pre-nursery. Abnormal seeds 
have little chance to develop and become productive plants with success. It is extremely important to eliminate this kind of abnormal seed in the screening process within the germination room.

As well as on the percentage of seed germination, mechanical depulping also did not negatively affect the expression of vigor by the IGS, in this experiment. The higher the IGS, the greater the speed of germination, which can be inferred that the seed lot is more strenuous and greater physiological quality. The average for IGS was $24.22 \%$, ranging from $32.43 \%$ to $19.90 \%$ (Table 1 ).

The amounts related to the viability and vigor by tetrazolium test showed an average ranging from $64 \%$ to 84\% (Table 1). These values allowed the framework of the treatments in the first three classes proposed by Green [17], which correspond to the variation of medium vigor until the high one. The result shows that the embryos of interspecific hybrid BRS Manicoré were vigorous, with value higher than $52 \%$ in the first three classes, as reported in the interpretation of this methodology procedure.

According to Zonta [28], when enzymatic activity is necessary to reduce trifenilformazan, embryos develop intense red coloration, indicating that there is vigorous and therefore living tissues. This characteristic was observed in embryos evaluated, where it was a tigelo homogeneous coloration (Figure 4(a) and Figure 4(b)) and a maximum of $50 \%$ of coloration absence for the haustoria (Figure 4(c)).

Through this study it was observed that the mechanical depulping, in the conditions of this experiment, did not interfere with percentage of germination of seeds, fungal incidence and abnormal seeds, neither on the viability and vigor of embryos. These results provided important practical applications during the production of commercial seeds, because, since mechanized depulping not affects the percentage of germination, the seeds can stay till 40 minutes within the mechanical depulper until complete removal of mesocarp, without the presence of broken seeds. This procedure will facilitate and accelerate the processing of seeds, since the manual removal of the mesocarp demand manpower and is time consuming.
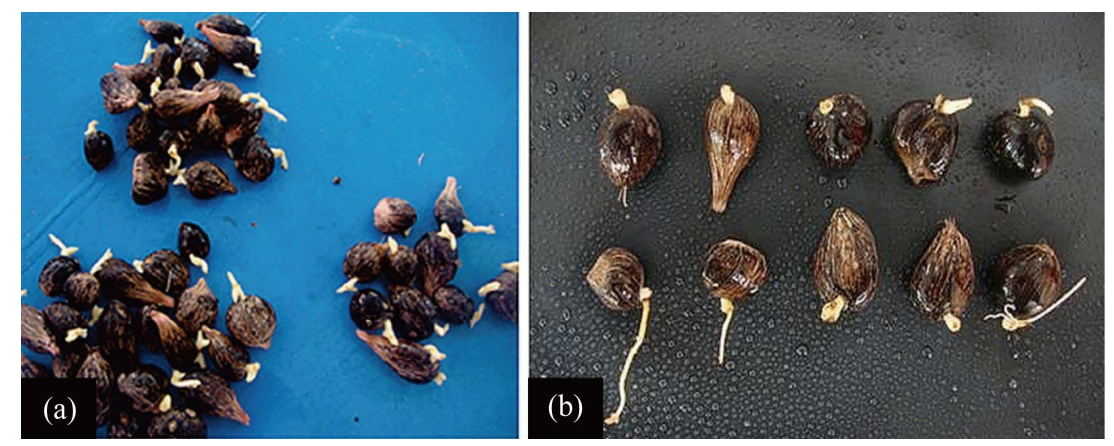

Figure 3. Different types of abnormalities in oil palm seed during the germination process. (a) Normal seed germination; (b) Seeds with abnormalities (MORA et al., 2007). Images from Embrapa Products and Markets-Escritório de Negócios da Amazônia, 2014.

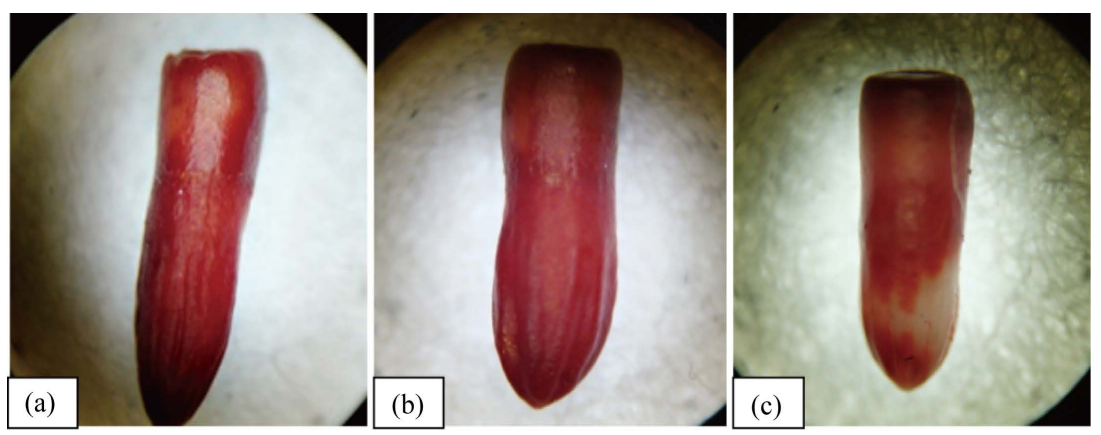

Figure 4. Embryous from the interespecific hybrid BRS Manicoré (Elaeis oleifera $\times$ E. guineensis) from classes: (a) class 1 (the most high vigor): homogeneouscoloring (red or pink); (b) class 2 (high vigor): haustorium less than 25\% colorless; and (c) class 3 (medium vigor): haustorium between $25 \%$ to $50 \%$ without color below the median region. 


\section{Conclusion}

The mechanical depulping, in the conditions of this experiment, does not affect the percentage of seed germination, nor the viability and vigor of embryos HIE BRS Manicoré. Furthermore, the seeds can remain for up to 40 minutes in the mechanical depulper to the complete removal of mesocarp without mechanical damage, reducing the time consuming practice of manual removal of mesocarp.

\section{References}

[1] Da Cunha, R.N.V. and Lopes, R. (2010) BRS Manicoré: Híbrido Interespecífico entre o Caiaué e o Dendezeiro Africano Recomendado para Áreas de Incidência de Amarelecimento-Fatal. Comunicado Técnico 85, Embrapa Amazônia Ocidental, Manaus, 4.

[2] Cunha, R., lopes, R., Dantas, J.C.R. and Rocha, R.N.C. (2007) Procedimento para produção de sementes comerciais de dendezeiro na Embrapa Amazônia Ocidental. Embrapa Amazônia Ocidental, Manaus, 34.

[3] Hussey, G. (1958) An Analysis of the Factors Controlling the Germination of the Seed of the Oil Palm, Elaeis guineensis (Jacq.). Annals of Botany, 22, 259-286.

[4] De Lima, W.A.A., Da Cunha, R.N.V., Lopes, R., Green, M., Abreu, S.C. and Simonetti, R. (2013) Produção de sementes germinadas de dendezeiro (Elaeis guineensis, Jacq.) na Embrapa. Embrapa Amazônia Ocidental, Manaus, 14.

[5] Guerrero, J., Bastidas, S. and Garcia, J. (2011) Estandarizacion de una metodologia para germinar semillas del hibrido interespecifico Elaeis oleifera H.B.K. × Elaeis guineensis Jaq. Revista De Ciencias Agricolas, 28, 132-146,.

[6] Mcdonald, M.B. (2004) Orthodox Seed Deterioration and Its Repair. In: Benech-Arnold, R.L. and Sánchez, R.A., Eds., Handbook of Seed Physiology, Application to Agriculture, Haworth Press, Inc., New York, 273-298.

[7] Fondom, N.Y., Etta, C.E. and Mih, A.M. (2010) Breaking Seed Dormancy: Revisiting Heat-Treatment Duration on Germination and Subsequent Seedling Growth of Oil Palm (EIaeis guineensis Jacq.) Progenies. Journal of Agricultural Science, 2, 101-110.

[8] Myint, T., Chanpraset, W. and Srikul, S. (2010) Germination of Seef of Oil Palm (Elaeis guineensis Jacq.) as Affected by Different Mechanical Scarification Methods. Seed Science and Technology, 38, 635-645. http://dx.doi.org/10.15258/sst.2010.38.3.11

[9] Chanprasert, W., Mynt, T., Srikul, S. and Wongsri, O. (2012) Effects of Neonicotinoid and Method of Breaking Dormancy on Seed Germination and a Seedling Vigour of Oil Palm (Elaeis guineensis Jacq.). Journal of Oil Palm Research, 24, 1227-1234.

[10] Schmidt, L. (2000) Guide to Handling of Tropical and Subtropical Forest Seed. Danida Forest Seed Centre. Humlebaek, Denmark, 511.

[11] Escobar, R. (1980) An Improved Oil Palm Fruit Depulper for Single Bunch Lots. Planters, 56, 540-542.

[12] Bewley, J.D. and Black, M. (1994) Seeds Physiology of Development and Germination. 3rd Edition, Plenum Press, New York, 445 p.

[13] da Silva, E.A.A., de Melo, D.L.B., Davide, A.C., de Bode, N., Abreu, G.B., Faria, J.M.R. and Hilhorst, H.W.M. (2007) Germination Ecophysiology of Annona crassiflora Seeds. Annals of Botany, 99, 823-830. http://dx.doi.org/10.1093/aob/mcm016

[14] Araújo, E.F., Reis, L.S., Meireles, R.C. and Serrano, L.A.S. (2004) Efeito da danificação mecânica e da remoção manual do pergaminho sobre a emergência de plântulas de Coffea arabica L. Revista Brasileira de Armazenamento, 8, $1-5$.

[15] Fagundes, A.V., Rosa, S.D.V.F. and Ribeiro, F.L.F. (2009) Aceleração da formação de mudas de Coffea arábica L., cultivar “Topázio” em função da retirada do pergaminho. Revista Brasileira de Armazenamento, 11, 1-6.

[16] Maguire, J.D. (1962) Speed of Germination-Aid in Selection and Evaluation for Seedling Emergence and Vigor. Crop Science, 2, 176-177. http://dx.doi.org/10.2135/cropsci1962.0011183X000200020033x

[17] Green, M. (2012) Avaliação da qualidade de sementes de dendezeiro (Elaeis guineensis Jacq.) produzidas pela Embrapa Amazônia Ocidental. Tese (Doutorado), Universidade Federal do Amazonas Amazonas, Manaus, 79 p.

[18] Murugesan, P., Vanangamudi, K. and Umarani, R. (2002) Evaluation of Viability of Oil Palm (Elaeis guineensis Jacq.) Seeds by Tetrazolium Test and Comparison with Germination and in Vitro Culture Results. Proceedings of Placrosym $X V$, Mysore, 10-13 December 2002, 246-250.

[19] Cruz, C.D. (2006) Programa Genes: Versão Windows-Aplicativo computacional em genética e estatística. UFV, Viçosa, 42.

[20] Robinson, M.L. (2009) Cultivated Palm Seed Germination. Cooperative Extension, University of Nevada. http://www.unce.unr.edu/publications/files/ho/2002/sp0209.pdf 
[21] Li, A., Herrera, J. and Barboza, R. (1996) Efecto del envejecimiento acelerado sobre la germinación y el vigor de la semilla de china sultani (Impatiens wallerana) en almácigo. Agronomía Costarricense, 20, 173-180.

[22] Hartley, C. (1988) The Oil Palm. 3rd Edition, Editorial Longman, London, 958.

[23] Mora, S., Chinchilla, C., Sánchez, A. and Escobar, R. (2007) Innovación en los procesos para mejorar la calidad de las semillas germinadas y de lãs plántulas de palma aceitera. Palmas, 28, 265-272. http://publicaciones.fedepalma.org/index.php/palmas/article/download/1263/1263

[24] Dussert, S., Guerin, C., Andersson, M., Joët, T., Tranbarger, T.J., Pizot, M., Sarah, G., Omore, A., Durand-Gasselin, T. and Morcillo, F. (2013) Comparative Transcriptome Analysis of Three Oil Palm Fruit and Seed Tissues That Differ in Oil Content and Fatty Acid Composition. Plant Physiology, 162, 1337-1358. www.plantphysiol.org/cgi/doi/10.1104/pp.113.220525

[25] Ngalle, H.B., Bell, J.M., Ebongue, G.F.N., Nyobe, L., Ngangnou, F.C. and Ntsomboh, G.N. (2013) Morphogenesis of Oil Palm Fruit (Elaeis guineensis Jacq.) in Mesocarp and Endocarp Development. Journal of Life Sciences, 7, 153-158.

[26] Siqueira, V.K.S., Hanada, R.E. and Lima, W.A.A. (2012) Incidência de Fungos em Sementes de Híbrido Interespecífico BRS-Manicoré. Tropical Plant Pathology, 38, 798.

[27] Piveta, G., Menezes, V.O., Pedroso, D.C., Muniz, M.F.B., Blume, E. and Wielewicki, A.P. (2010) Superação de dormência na qualidade de sementes e mudas: Influência na produção de Senna multijuga (L. C. Rich.) Irwin \& Barneby. Acta Amazônica, 40, 281-288.

[28] Zonta, J.B., de Souza, L.T., Dos Santos Dias, D.C.F. and Alvarenga, E.M. (2009) Comparação de meto-dologias do teste de tetrazólio para sementes de cafeeiro. Idesia, 27.

http://www.scielo.cl/scielo.php?script=sci_arttext\&pid=S0718-34292009000200002\&lng=en\&nrm=iso 
Scientific Research Publishing (SCIRP) is one of the largest Open Access journal publishers. It is currently publishing more than 200 open access, online, peer-reviewed journals covering a wide range of academic disciplines. SCIRP serves the worldwide academic communities and contributes to the progress and application of science with its publication.

Other selected journals from SCIRP are listed as below. Submit your manuscript to us via either submit@scirp.org or Online Submission Portal.
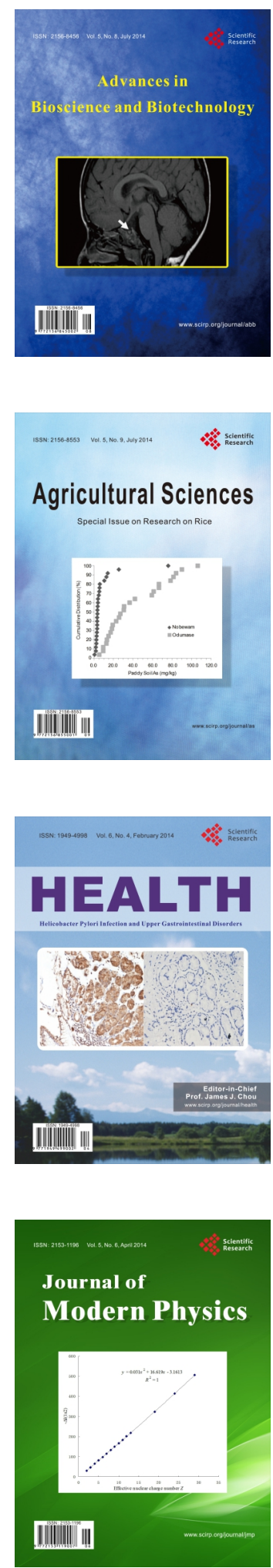
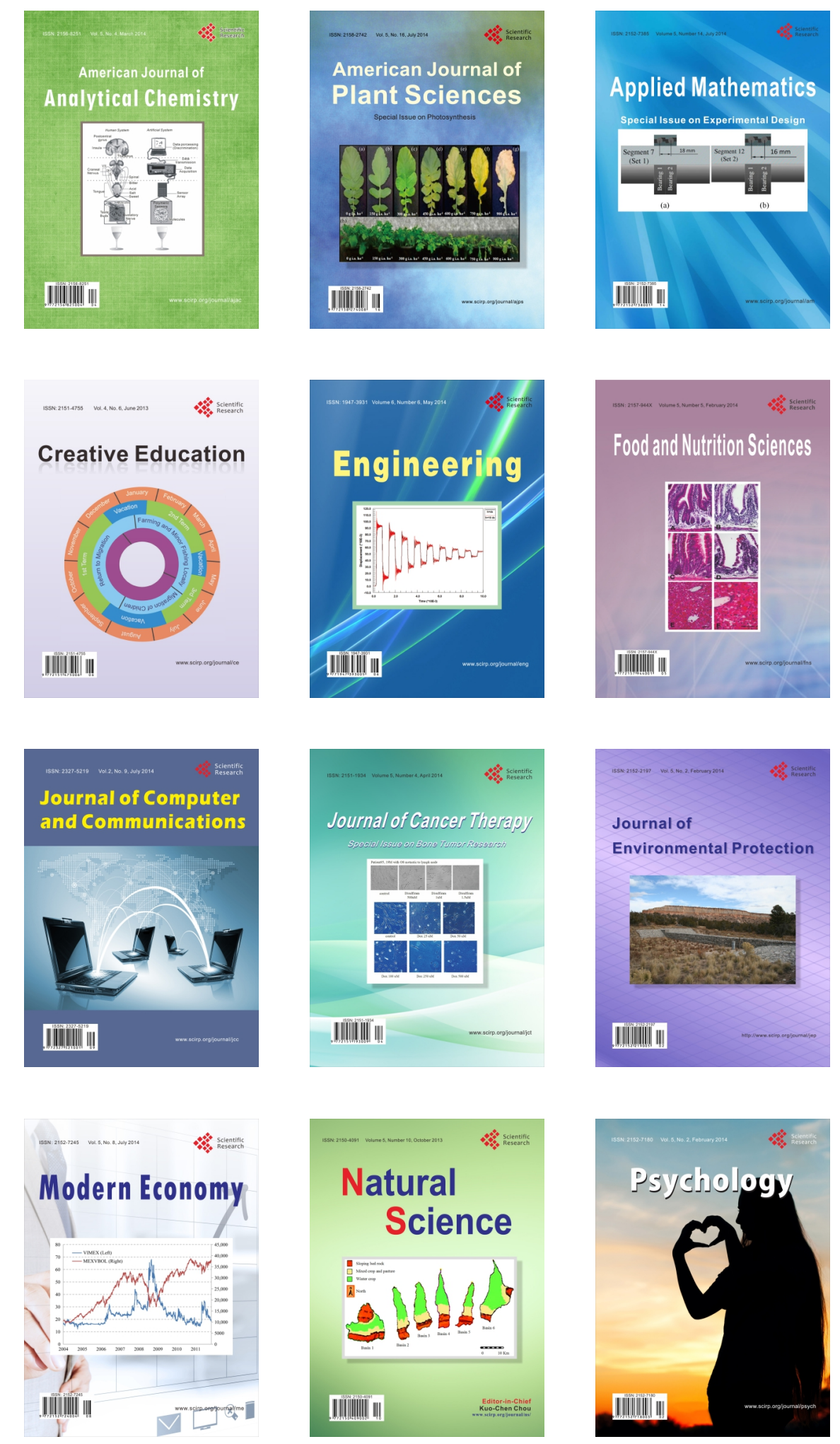